\title{
Kinetic and Structural Characterization of a Two-domain Streptokinase: Dissection of Domain Functionality ${ }^{\dagger}$
}

\author{
Laust B. Johnsen, ${ }^{\ddagger}$ Lone K. Rasmussen, ${ }^{\ddagger}$ Torben E. Petersen, ${ }^{*}, \$$ Michael Etzerodt, ${ }^{\S}$ and Sergey N. Fedosov \\ Protein Chemistry Laboratory and Laboratory of Gene Expression, Department of Molecular and Structural Biology, \\ University of Aarhus, Science Park, Gustav Wieds vej 10 C, DK-8000 Aarhus C, Denmark
}

Received September 27, 1999; Revised Manuscript Received February 8, 2000

\begin{abstract}
The mammalian protease plasminogen can be activated by bacterial activators, the threedomain $(\alpha, \beta, \gamma)$ streptokinases and the one-domain $(\alpha)$ staphylokinases. These activators act as plasmin(ogen) cofactors, and the resulting complexes initiate proteolytic activity of host plasminogen which facilitates bacterial colonization of the host organism. We have investigated the kinetic mechanism of the plasminogen activation mediated by a novel two-domain $(\alpha, \beta)$ streptokinase isolated from Streptococcus uberis $\left(\mathrm{Sk}^{\mathrm{U}}\right)$ with specificity toward bovine plasminogen. The interaction between $\mathrm{Sk}^{\mathrm{U}}$ and plasminogen occurred in two steps: (1) rapid association of the proteins and (2) slow transition to the active complex $\mathrm{Sk}^{\mathrm{U}}-\mathrm{PgA}$. The complex $\mathrm{Sk}^{\mathrm{U}}-\mathrm{PgA}$ converted plasminogen to plasmin with the following parameters: $K_{\mathrm{m}} \leq 1.5 \mu \mathrm{M}$ and $k_{\mathrm{cat}}=0.55 \mathrm{~s}^{-1}$. The ability of proteolytic fragments of $\mathrm{Sk}^{\mathrm{U}}$ to activate plasminogen was investigated. Only two C-terminal segments (97-261 and 123-261), which both contain the $\beta$-domain (126-261), were shown to be active. They initiated plasminogen activation in complex with plasmin, but not with plasminogen, and thereby exhibited functional similarity to the staphylokinase. The fusion protein $\mathrm{His}_{6}-\mathrm{Sk}^{\mathrm{U}}$ (i.e., $\mathrm{Sk}^{\mathrm{U}}$ with a small $\mathrm{N}$-terminal tag) acted exclusively in complex with plasmin as well. These observations demonstrate that (1) the $\mathrm{N}$-terminal $\alpha$-domain, including a native $\mathrm{N}$-terminus, was necessary for "virgin" activation of the associated plasminogen in the $\mathrm{Sk}^{\mathrm{U}}-\mathrm{PgA}$ complex and (2) the $\mathrm{C}$-terminal $\beta$-domain of $\mathrm{Sk}^{\mathrm{U}}$ is important for recognition of the substrate in the $\mathrm{Sk}^{\mathrm{U}}-\mathrm{PgA}$ complex.
\end{abstract}

Plasmin $(\mathrm{Pn})^{1}$ is a potent mammalian proteinase which has several important physiological functions such as blood clot dissolution (fibrinolysis), cellular migration, and cancer metastasis. The zymogen of Pn, called plasminogen $(\mathrm{Pg})$, is synthesized in the liver and found in blood and extracellular fluids. Two specific proteins, tissue-type and urokinase-type $\mathrm{Pg}$ activators (tPA and $\mathrm{UPA}$, respectively), convert Pg into $\mathrm{Pn}$. In addition to these two physiological Pg activators, several microbial pathogens synthesize their own activators with specificity toward host $\operatorname{Pg}(1,2)$. Generation of $\mathrm{Pn}$ assists the pathogenic microorganism in proteolysis of fibrin and other proteins in the extracellular matrix. This, in turn,

\footnotetext{
$\doteqdot$ This work is part of the FØTEK program supported by the Danish Dairy Research Foundation (Danish Dairy Board) and the Danish Government.

* Corresponding author.

Protein Chemistry Laboratory.

$\S$ Laboratory of Gene Expression.

${ }^{1}$ Abbreviations: [Asp ${ }^{1}$ ]plasminogen, native form of bovine plasminogen with an aspartic acid at the N-terminus; $\alpha_{2}$ - $\mathrm{AP}, \alpha_{2}$-antiplasmin; $\mathrm{bPg}$, bovine plasminogen; $\mathrm{Fb}$, fibrinogen; [ $\left.\mathrm{Glu}^{1}\right]$ plasminogen, native form of human plasminogen with a glutamic acid at the N-terminus; $\mathrm{hPg}$, human plasminogen; $\mathrm{His}_{6}-\mathrm{Sk}^{\mathrm{U}}$, the fusion streptokinase with an $\mathrm{N}$-terminal His-tag and factor Xa site; Pg, plasminogen; Pn, plasmin; Sak, staphylokinase from Staphylococcus aureus; SE-HPLC, sizeexclusion HPLC.; $\mathrm{Sk}^{\mathrm{E}}$, traditional streptokinase isolated from various human isolates of hemolytic Streptococcus equisimilis and Streptococcus pyogenes strains; $\mathrm{Sk}^{\mathrm{U}}$, streptokinase from Streptococcus uberis; $\mathrm{Sk}{ }^{\mathrm{U}}-\mathrm{Pg}$, inactive complex; $\mathrm{Sk}{ }^{\mathrm{U}}-\mathrm{PgA}$, active complex; $\mathrm{Sk}^{\mathrm{N}}$, a proteolytic fragment of $\mathrm{Sk}^{\mathrm{U}}$; tPA, tissue-type plasminogen activator; uPA, urokinase-type plasminogen activator.
}

facilitates the bacterial penetration of normal tissue barriers and enables bacterial colonization of deep tissue sites (1). The best known activators are the streptokinases $\left(\mathrm{Sk}^{\mathrm{E}}\right)$ isolated from S. equisimilis and the staphylokinases (Sak) from S. aureus. These proteins have been studied extensively because of their high fibrinolytic potential and specificity toward human $\mathrm{Pg}$. $\mathrm{Sk}^{\mathrm{E}}$ is currently used as a drug in thrombolytic therapy.

The activators from different sources are characterized by different features of their Pg activation mechanisms. The physiological activators (tPA and uPA) convert Pg to Pn by hydrolysis of the $\operatorname{Arg}_{561}-\mathrm{Val}_{562}$ peptide bond. Subsequent formation of a salt bridge between the newly formed $\mathrm{N}$-terminal amino group of $\mathrm{Val}_{562}$ and the carboxyl group of $A_{\mathrm{sp}_{740}}$ induces the active conformation of the enzyme. This scheme is analogous to the well-studied mechanism employed by other chymotrypsin-like proteases. The bacterial activators $\mathrm{Sk}^{\mathrm{E}}$ and $\mathrm{Sak}$ are not proteases but act as cofactors in $\mathrm{Pg}-\mathrm{Sk}^{\mathrm{E}}$ or $\mathrm{Pn}-\mathrm{Sak}$ complexes that dramatically alter the specificity of the associated plasmin(ogen) from that of a nonplasminogen activator into that of a highly efficient one. Binding of $\mathrm{Sk}^{\mathrm{E}}$ to $\mathrm{Pg}$ changes the conformation of the serine proteinase domain in the associated Pg. This causes exposure of the active site of the proteinase without its proteolytic cleavage, thereby providing the $\mathrm{Sk}^{\mathrm{E}}-\mathrm{Pg}$ complex with "virgin" enzymatic activity supplemented by affinity toward free $\mathrm{Pg}$ (3). Sak cannot induce the corresponding transformation, and the complex $\mathrm{Sak}-\mathrm{Pg}$ is proteolytically inactive. 
Only complex formation between Sak and the active protease Pn produces a construction which combines the proteolytic ability with the specificity toward $\operatorname{Pg}(4,5)$.

The identification of the regions in $\mathrm{Sk}^{\mathrm{E}}$ and Sak responsible for virgin activation of $\mathrm{Pg}$ as well as activation of substrate $\mathrm{Pg}$ has become a controversial issue. The structures of the ternary microplasmin-Sak-microplasmin complex and the microplasmin $-\mathrm{Sk}^{\mathrm{E}}$ complex were recently solved $(6,7)$. They revealed a striking similarity of the single $\alpha$-domain of Sak to the $\mathrm{N}$-terminal $\alpha$-domain and the central $\beta$-domain of $\mathrm{Sk}^{\mathrm{E}}$, but less so to the C-terminal $\gamma$-domain of $\mathrm{Sk}^{\mathrm{E}}$. The structure of the ternary enzyme-substrate complex, microplasmin-Sak-microplasmin, revealed detailed structural information on the protein-protein interactions resulting in activator complex formation and substrate recognition (6). However, the mechanism whereby $\mathrm{Sk}^{\mathrm{E}}$ induces virgin activity in the $\mathrm{Sk}^{\mathrm{E}}-\mathrm{Pg}$ complex was not evident from the microplasmin $-\mathrm{Sk}^{\mathrm{E}}$ structure (7). Still, interactions between the $\gamma$-domain of $\mathrm{Sk}^{\mathrm{E}}$ and the autolysis loop of $\mathrm{Pg}$ were proposed to trigger the activation $(7,8)$. In contrast, arguments based on functional studies of a $\mathrm{Sk}^{\mathrm{E}}$ mutant lacking the N-terminal Ile residue have claimed that $\mathrm{Sk}^{\mathrm{E}}$ activates $\mathrm{Pg}$ according to the molecular sexuality hypothesis, where the N-terminal Ile of $\mathrm{Sk}^{\mathrm{E}}$ mimics the function of the plasmin $\mathrm{Val}_{562} \mathrm{~N}$-terminus generated by activation cleavage with tPA or uPA (9). Also on the basis of the crystal structure of the microplasmin$\mathrm{Sk}^{\mathrm{E}}$ complex, the $\alpha$-domain was proposed to enhance substrate recognition of the activator complex. Furthermore, other functional studies have indicated that several regions in both the $\alpha$ - and $\beta$-domains are involved in substrate recognition, and regions in the $\beta$-domain have likewise been suggested to be essential for activator complex formation $(10-12)$.

We have recently described the purification and cloning of a two-domain $(\alpha, \beta)$ streptokinase from S. uberis $\left(\mathrm{Sk}^{\mathrm{U}}\right)$ with specificity toward bovine $\mathrm{Pg}$ (13). In this paper, we characterize the $\mathrm{Pg}$ activation mediated by recombinant $\mathrm{Sk}^{\mathrm{U}}$, the $\mathrm{Sk}^{\mathrm{U}}$ fragments, and the $\mathrm{N}$-terminal-modified fusion protein. Kinetic data indicated that $\mathrm{Sk}^{\mathrm{U}}$ (despite the absence of the $\gamma$-domain) could induce virgin enzymatic activity in bovine $\mathrm{Pg}$. The isolated C-terminal $\beta$-domain of $\mathrm{Sk}^{\mathrm{U}}$ (as well as $\mathrm{Sk}^{\mathrm{U}}$ with the $\mathrm{N}$-terminal tag) was incapable of virgin activation of $\mathrm{Pg}$, but formed an activation complex with Pn.

\section{MATERIALS AND METHODS}

Chemicals and Reagents. Super Taq polymerase was from HT Biotechnology (Cambridge, United Kingdom), nucleotide triphosphates were from Amersham Pharmacia Biotech (Uppsala, Sweden), oligonucleotides were from DNA technology (Aarhus, Denmark), and all other enzymes were from New England Biolabs (Hitchin, United Kingdom). PCR was performed in a Hybaid ABACUS thermal cycler (Middlesex, United Kingdom). Sequencing was performed with a dye terminator cycle sequencing kit from Perkin-Elmer (Foster City, CA). Sequencing, ligation, transformation of Escherichia coli, DNA preparation, PCR, and other DNA-modifying processes were carried out according to the manufacturers' recommendations or standard laboratory procedures. Yeast extract and tryptone were from DIFCO, and rifampicin was from ICN Biomedicals (Aurora, OH). BL21 cells were purchased from Stratagene (La Jolla, CA). Factor Xa protease immobilized on the column was from Protein Engineering Technology (Aarhus, Denmark), and trypsin, elastase, and chymotrypsin were from Worthington (Freehold, NJ). S-2251 (H-D-Val-Leu-Lys-pNA) was obtained from Chromogenix (Mölndal, Sweden). Bovine [Asp $\left.{ }^{1}\right]$ plasminogen (bPg), human $\left[\mathrm{Glu}^{1}\right]$ plasminogen $(\mathrm{hPg})$, human $\alpha_{2}$-antiplasmin, and streptokinase secreted from a $\beta$-hemolytic streptococcus $\left(\mathrm{Sk}^{\mathrm{E}}\right)$ were from American Diagnostica (Greenwich, CT). Bovine plasmin was from Boehringer Mannheim (Mannheim, Germany). All plasminogens, free of 6-aminohexanoic acid, used in the species-specific experiment were obtained from Sigma (St. Louis, MO.). Bovine $\mathrm{CNBr}$-fibrinogen fragments were prepared as described previously (14). The plasminogen used for zymography was prepared from intravenously collected bovine plasma and purified by chromatography on lysineSepharose followed by gel filtration in the presence of the serine protease inhibitors phenylmethylsulfonyl fluoride, benzamidine, and soybean trypsin inhibitor obtained from Sigma. Pg-depleted bovine fibrinogen $(\mathrm{Fb})$ was purchased from Enzyme Research Laboratories (South Bend, IN).

Expression of $S k^{U}$. The full-length native $\mathrm{Sk}^{\mathrm{U}}$ sequence was amplified by PCR using a previously isolated genomic fragment as template (13) and the corresponding primers: the forward primer 5'-CGCGGATCCATCCAGGGTCGTATAACCGGTTATGATTCCG-3' containing a BamHI restriction site and a factor Xa-encoding cleavage site (IQGR ${ }^{\downarrow}$ ); the reverse primer $5^{\prime}$-CGCGGATCCTTAAGGTTTATAACTTTTTTTGG-3' also containing a BamHI restriction site. The amplified fragment was digested with BamHI and subcloned into the expression vector pT7H6gs (15) derived from the plasmid pBR328. The resulting expression plasmid pT7H6gs $-\mathrm{Sk}^{\mathrm{U}}$ had the ability to express the native $\mathrm{Sk}^{\mathrm{U}}$ with an N-terminal His-tag followed by a factor $\mathrm{Xa}$ cleavage site. The identity of $\mathrm{Sk}^{\mathrm{U}}$ was confirmed by sequencing on both strands. Expression was performed in 1 $\mathrm{L}$ portions of $2 \mathrm{xYT}$ medium supplemented with $0.1 \mathrm{~g}$ of ampicillin, $10 \mathrm{mM} \mathrm{MgSO}_{4}$, and $15 \mathrm{~mL}$ of a culture of pT7H6gs $-\mathrm{Sk}^{\mathrm{U}}$ recombinant BL21 cells. Expression was induced at $\mathrm{OD}_{600}=0.8$ by adding bacteriophage $\lambda$-CE-6 (16). After $50 \mathrm{~min}$ of incubation, rifampicin $(100 \mathrm{mg} / \mathrm{L})$ was added, and expression was continued for $3.5 \mathrm{~h}$ followed by harvesting at $3000 \mathrm{~g}$ for $5 \mathrm{~min}$.

Purification and Cleavage with Factor Xa. Cells from 1 $\mathrm{L}$ of the medium were resuspended in $20 \mathrm{~mL}$ of $100 \mathrm{mM}$ Tris- $\mathrm{HCl}, \mathrm{pH} 8.0,0.5 \mathrm{M} \mathrm{NaCl}, 2 \mathrm{mM}$ EDTA, and $20 \mathrm{mM}$ dithiotreitol. Afterward, $100 \mathrm{~mL}$ of phenol, $\mathrm{pH}$ 8.0, was added, and the suspension was hand-shaken and left at room temperature for $10 \mathrm{~min}$. The lysed cells were then sonicated for $15 \mathrm{~min}$ and centrifuged (15 min, 10000g), and the phenol phase was collected. Proteins were precipitated from the phenol phase by $2.5 \mathrm{vol}$ of $96 \%$ ethanol, centrifuged (20 min, $3000 \mathrm{~g}$ ), and dissolved in $10 \mathrm{~mL}$ of $6 \mathrm{M}$ guanidinium$\mathrm{HCl}, 50 \mathrm{mM}$ Tris $-\mathrm{HCl}$, pH 8.0. The solubilized mixture was centrifuged (15 $\mathrm{min}, 10000 \mathrm{~g}$ ), and the recombinant protein was adsorbed on $\mathrm{Ni}-\mathrm{NTA}$ resin by batch incubation. The matrix with bound $\mathrm{His}_{6}-\mathrm{Sk}^{\mathrm{U}}$ was packed in a $40 \mathrm{~mL}$ column, washed with 1 vol of $6 \mathrm{M}$ guanidinium- $\mathrm{HCl}, 50 \mathrm{mM}$ Tris$\mathrm{HCl}, \mathrm{pH} 8.0$, followed by several volumes of $8 \mathrm{M}$ urea, 0.5 $\mathrm{M} \mathrm{NaCl}, 50 \mathrm{mM}$ Tris- $\mathrm{HCl}, \mathrm{pH} 8.0$, until $A_{280}$ became stable. Afterward, the protein was refolded in the column by changing the buffer to $150 \mathrm{mM} \mathrm{NaCl}, 50 \mathrm{mM}$ Tris- $\mathrm{HCl}$, $\mathrm{pH}$ 8.0. Elution was performed in the same buffer supple- 
mented with $10 \mathrm{mM}$ EDTA. The eluate was concentrated on an Amicon-10 membrane, and the $\mathrm{N}$-terminal $\mathrm{His}_{6}$ peptide was cleaved in a column with the coupled factor Xa at $4{ }^{\circ} \mathrm{C}$ until approximately half of the sites were cleaved. The native streptokinase was separated from the remaining fusion protein by passage through $\mathrm{Ni}-\mathrm{NTA}$ resin in $500 \mathrm{mM} \mathrm{NaCl}$, $50 \mathrm{mM}$ Tris $-\mathrm{HCl}, \mathrm{pH}$ 8.0. The recombinant protein was eluted in the unbound fraction and dialyzed against $20 \mathrm{mM}$ $\mathrm{NH}_{4} \mathrm{HCO}_{3}$. The sample was freeze-dried, resolubilized in 50 $\mathrm{mM}$ Tris $-\mathrm{HCl}, \mathrm{pH} 7.5$, at a concentration of $3 \mathrm{mg} / \mathrm{mL}$, and stored at $-20{ }^{\circ} \mathrm{C}$.

Limited Proteolysis. Elastase, trypsin, and chymotrypsin were incubated with $\mathrm{Sk}^{\mathrm{U}}$ at a ratio of $1: 400(\mathrm{w} / \mathrm{w})$ at $37^{\circ} \mathrm{C}$. Samples were taken at time intervals and analyzed by SDSPAGE. $\mathrm{Sk}^{\mathrm{U}}$ fragments were purified by reversed-phase HPLC on a Vydac $\mathrm{C}_{18}$ column (Hesperia, CA). Identification of the fragments was carried out by sequencing on an ABI 477/ $120 \mathrm{~A}$ protein sequencer (PE Applied Biosystems, Foster City, CA).

Determination of Molecular Masses by SE-HPLC. Gel filtration of $\mathrm{Sk}^{\mathrm{U}}$ and $\mathrm{Sk}^{\mathrm{E}}$ was performed on a SMART HPLC system (Amersham Pharmacia Biotech, Uppsala, Sweden) equipped with a Superdex 75 PC 3.2/30 column equilibrated with $50 \mathrm{mM}$ Tris $-\mathrm{HCl}, \mathrm{pH} 7.5,100 \mathrm{mM} \mathrm{NaCl}$ at room temperature. The following mixture of proteins was used for calibration: cytochrome $c(12.4 \mathrm{kDa}), \beta$-lactoglobulin (35 $\mathrm{kDa})$, bovine serum albumin (67 kDa), and IgG (160 kDa). Formation of $\mathrm{Sk}^{\mathrm{U}}-\mathrm{bPg}$ and $\mathrm{Sk}^{\mathrm{E}}-\mathrm{hPg}$ complexes was carried out at approximately equimolar protein concentrations $(2 \mu \mathrm{M})$ at room temperature for $15 \mathrm{~min}$ in the running buffer supplemented with $0.05 \mathrm{mM}$ protease inhibitor $p$-nitrophenyl $p$-guanidinobenzoate (17). The complexes were detected by gel filtration on a Superose 12 PC 3.2/30 column (Amersham Pharmacia Biotech, Uppsala, Sweden) equilibrated with 0.2 M sodium phosphate, $\mathrm{pH}$ 6.8, $20 \mathrm{mM}$ 6-aminohexanoic acid.

Zymography. Zymography was performed as described previously by Andreasen et al. (18) using standard SDSPAGE conditions and agarose gels containing bovine fibrinogen $(1.7 \mathrm{mg} / \mathrm{mL})$ and bovine $\operatorname{Pg}(8 \mu \mathrm{g} / \mathrm{mL})$. Fibrin polymerization was initiated by human thrombin $(0.03$ $\mathrm{U} / \mathrm{mL}$ ).

Plasminogen Activation Assays. All experiments (both here and below) have been performed in the following medium: $50 \mathrm{mM}$ Tris $-\mathrm{HCl}, \mathrm{pH} 7.4,100 \mathrm{mM} \mathrm{NaCl}, 0.15 \%$ Tween 20, and $0.5 \mathrm{mM} \mathrm{S}-2251$. Determination of $v_{\mathrm{a}}$ and $k_{*}$ (see the Kinetic Analysis of Plasminogen Activation) was carried out at $37{ }^{\circ} \mathrm{C}$ in a total volume of $0.3 \mathrm{~mL}$ with final concentrations of $\mathrm{Sk}^{\mathrm{U}}$ at $1 \mathrm{nM}$ and $\mathrm{Pg}$ at $0.02-3.0 \mu \mathrm{M}$. The reaction was initiated by addition of $0.1 \mathrm{~mL}$ of $\mathrm{Sk}^{\mathrm{U}}+\mathrm{S}-2251$ to $0.2 \mathrm{~mL}$ of Pg and monitored at $405 \mathrm{~nm}$ in a Camspec M350 double beam UV-Vis spectrophotometer (Camspec Ltd., United Kingdom). Other assays were performed in microtiter plates at room temperature, and changes of absorbency were followed in a Bio-Tek EL 340 Biokinetics Reader (Bio-Tek Instruments Inc., Winooski, VT).

Fibrinogen or CNBr-Fibrinogen Stimulation. $\operatorname{Pg}(0.1 \mu \mathrm{M})$ in the reaction mixture was preincubated for $5 \mathrm{~min}$ with various amounts of $\mathrm{Fb}$ or $\mathrm{CNBr}-\mathrm{Fb}$, and the reactions were initiated by addition of $0.1 \mathrm{nM} \mathrm{Sk}^{\mathrm{U}}$.

Plasminogen Activation Mediated by the $S k^{U}$ Fragment (97-261). In one setup, consumption of S-2251 was followed in time at $0.1 \mu \mathrm{MPg}$ and various amounts of $\mathrm{Sk}^{\mathrm{U}, 97-261}$
$(0.1-0.8 \mu \mathrm{M})$ at $20^{\circ} \mathrm{C}$. In another experiment, the reaction was monitored at fixed amounts of $\mathrm{Sk}^{\mathrm{U}, 97-261}(0.25 \mu \mathrm{M})$ and Pg $(0.1 \mu \mathrm{M})$ on the background of different concentrations of Pn $(0-2500 \mathrm{pM})$. In assays where suppression of endogenous Pn was required, Pg was preincubated with $\alpha_{2-}$ $\mathrm{AP}$ at the ratio 100:1 for $3 \mathrm{~h}$ before initiation of the reaction.

Inhibition of the $\mathrm{Sk}^{U}-\mathrm{Pg}$ Complex Activity by $\mathrm{\alpha}_{2}$-Antiplasmin or $S k^{U}$ Fragments. Suppression of the amidase activity of $\mathrm{Sk}^{\mathrm{U}}-\mathrm{Pg}$ toward $\mathrm{S}-2251$ was monitored when 0.1 $\mu \mathrm{M}$ Pg and $0.3 \mu \mathrm{M} \alpha_{2}$-AP were preincubated for $1 \mathrm{~min}$ in the reaction mixture $\left(20^{\circ} \mathrm{C}\right)$ followed by addition of $0.2 \mu \mathrm{M}$ $\mathrm{Sk}^{\mathrm{U}}$. Inhibition of the proteinase activity of $\mathrm{Sk}^{\mathrm{U}}-\mathrm{Pg}$ toward free $\mathrm{Pg}$ was measured when the mixture $10 \mathrm{nM} \mathrm{Sk}^{\mathrm{U}}+10$ $\mathrm{nM} \mathrm{Pg}+30 \mathrm{nM} \alpha_{2}$-AP was preincubated for $1 \mathrm{~h}$ and then added to the reaction medium with $0.1 \mu \mathrm{M} \mathrm{Pg}$ (final concentration of $\mathrm{Sk}^{\mathrm{U}} 0.5 \mathrm{nM}$ ). Inhibition of $\mathrm{Sk}^{\mathrm{U}}$-mediated $\mathrm{Pg}$ activation by $\mathrm{Sk}^{\mathrm{U}}$ fragments was registered after $1 \mathrm{~min}$ of incubation of $0.1 \mu \mathrm{M} \mathrm{Pg}$ with $0.2 \mu \mathrm{M}$ fragment in the reaction medium followed by addition of $1 \mathrm{nM} \mathrm{Sk}^{\mathrm{U}}$.

Plasminogen Activation Mediated by $\mathrm{His}_{6}-\mathrm{Sk}^{U}$. Catalytic $(1 \mathrm{nM})$ or saturating amounts $(0.2 \mu \mathrm{M})$ of $\mathrm{His}_{6}-\mathrm{Sk}^{\mathrm{U}}$ were added to the reaction medium with $0.1 \mu \mathrm{M} \mathrm{Pg}$, and the proteinase or amidase activity was followed in time. In assays where suppression of endogenous Pn was required, Pg was preincubated for $3 \mathrm{~h}$ with $\alpha_{2}$-AP at a ratio of 100:1, and the reaction was initiated by addition of $\mathrm{His}_{6}-\mathrm{Sk}^{\mathrm{U}}$.

Specificity of $\mathrm{Sk}^{U}$ toward Plasminogen from Different Species. In one setup, $0.01 \mathrm{U}$ of Pg from bovine, equine, human, porcine, rabbit, and caprine species was mixed with $1 \mathrm{nM} \mathrm{Sk}^{\mathrm{U}}$ in the reaction medium. In another setup, a mixture of $0.1 \mu \mathrm{M} \mathrm{Sk}{ }^{\mathrm{U}}$ and $0.1 \mu \mathrm{M} \mathrm{bPg}$ was incubated for $5 \mathrm{~min}$ followed by addition of $1 \mathrm{nM}$ complex to the reaction medium with $0.01 \mathrm{U}$ of $\mathrm{Pg}$ from different species.

Kinetic Analysis of Plasminogen Activation Mediated by $S k^{U}$. The process was followed in the coupled reaction assay described by the following reactions:

Model 1

$$
\begin{gathered}
\mathrm{Sk}^{\mathrm{U}}+\mathrm{Pg} \underset{k_{-\mathrm{al}}}{\stackrel{k_{+\mathrm{al}}}{\longrightarrow}} \mathrm{Sk}^{\mathrm{U}}-\mathrm{PgA} \\
\mathrm{Sk}^{\mathrm{U}}+\mathrm{Pg} \stackrel{K_{\mathrm{bl}}}{\Leftrightarrow} \mathrm{Sk}^{\mathrm{U}}-\mathrm{Pg} \underset{k_{-\mathrm{bl}}}{\stackrel{k_{+\mathrm{bl}}}{\longrightarrow}} \mathrm{Sk}^{\mathrm{U}}-\mathrm{PgA} \\
\mathrm{Sk}^{\mathrm{U}}-\mathrm{PgA}+\mathrm{Pg} \stackrel{K_{2}}{\Leftrightarrow} \mathrm{Sk}^{\mathrm{U}}-\mathrm{PgA}-\mathrm{Pg} \stackrel{k_{2}}{\longrightarrow} \mathrm{Sk}^{\mathrm{U}}-\mathrm{PgA}+\mathrm{Pn} \\
\mathrm{Pn}+\mathrm{S} \stackrel{K_{3}}{\leftrightarrow} \mathrm{Pn}-\mathrm{S} \stackrel{k_{3}}{\longrightarrow} \mathrm{Pn}+\mathrm{P} \\
\mathrm{Sk}^{\mathrm{U}}-\mathrm{PgA}+\mathrm{S} \stackrel{K_{4}}{\leftrightarrow} \mathrm{Sk}^{\mathrm{U}}-\mathrm{PgA}-\mathrm{S} \stackrel{k_{4}}{\longrightarrow} \mathrm{Sk}^{\mathrm{U}}-\mathrm{PgA}+\mathrm{P}
\end{gathered}
$$

Reactions $1 \mathrm{a}$ and $1 \mathrm{~b}$ represent two alternative mechanisms of interaction between $\mathrm{Sk}^{\mathrm{U}}$ and $\mathrm{Pg}$ : (1a) with direct formation of the catalytically active complex $\mathrm{Sk}^{\mathrm{U}}-\mathrm{PgA}$; (1b) with formation of an inactive intermediate, $\mathrm{Sk}^{\mathrm{U}}-\mathrm{Pg}$, followed by transition to the active complex $\mathrm{Sk}^{\mathrm{U}}-\mathrm{PgA} . k_{+\mathrm{a} 1}$ and $k_{-\mathrm{a} 1}$ are the rate constants of $\mathrm{Sk}^{\mathrm{U}}-\mathrm{PgA}$ formation according to reaction $1 \mathrm{a}, K_{\mathrm{b} 1}$ is the dissociation constant of $\mathrm{Sk}^{\mathrm{U}}-\mathrm{Pg}$ according to reaction $1 \mathrm{~b}, k_{+\mathrm{b} 1}$ and $k_{-\mathrm{b} 1}$ are the rate constants of transition between $\mathrm{Sk}^{\mathrm{U}}-\mathrm{Pg}$ and $\mathrm{Sk}^{\mathrm{U}}-\mathrm{PgA}$ according to reaction $1 \mathrm{~b}, K_{2}, K_{3}$, and $K_{4}$ are the Michaelis constants $\left(K_{\mathrm{m}}\right)$ of the corresponding enzymes, and $k_{2}$, and $k_{3}, k_{4}$ are the 
catalytic constants $\left(k_{\text {cat }}\right)$ of the corresponding enzymes. The values of $K_{4}$ and $k_{4}$ are expected to be close to $K_{3}$ and $k_{3}$ as follows from the data of Whol et al. (19). The process was followed at different $\mathrm{Pg}$ concentrations by liberation of $p$-nitroaniline $(\mathrm{P}), \epsilon_{405}=10000 \mathrm{M}^{-1} \mathrm{~cm}^{-1}$.

We have made one assumption to simplify the mathematical expression of the above model. Generation of the product (P) was exclusively ascribed to reaction 3 because $[\mathrm{Pn}] \gg$ $\left[\mathrm{Sk}^{\mathrm{U}}-\mathrm{PgA}\right]$ almost from the very beginning of the process. At the same time, the derived equations considered the participation of $\mathrm{Sk}^{\mathrm{U}}-\mathrm{PgA}$ in complex formation with $\mathrm{S}$ (reaction 4) which, to some extent, affects the apparent affinity of the activating complex to $\mathrm{Pg}$ (reaction 2). The time of the reaction was relatively short (4 min), and the appearance of the $\mathrm{Sk}^{\mathrm{U}}-\mathrm{Pn}$ complex, as well as proteolytic degradation of $\mathrm{Sk}^{\mathrm{U}}$, was ignored.

A general description of an analogous model has been given in our previous publication (14), and only the key steps of the analysis are mentioned here. The raw data ([P] versus time) were replotted in the coordinates $y$ versus $t^{2}$ (see below eqs I and II below), as such a transformation is necessary for an accurate analysis of the prestationary kinetics (14). The known parameters: $[\mathrm{S}]_{0}=500 \mu \mathrm{M}, K_{3}=200 \mu \mathrm{M}, k_{3}$ $=1000 \mathrm{~min}^{-1}(20)$ were used for conversion of $[\mathrm{P}]$ values to $y$ values by eq II. The prestationary phase (either reaction $1 \mathrm{a}$ or reaction $1 \mathrm{~b}$ ) would reveal itself in coordinates $y$ versus $t_{2}$ as an initial lag phase described by the observed rate coefficient $k_{*}$. The lag phase is expected to be followed by the linear steady-state phase characterized by the slope coefficient $v_{\text {a }}$ (the Pg activation velocity). Both $k_{*}$ and $v_{\text {a }}$ can be calculated by nonlinear regression analysis of the experimental points according to (14)

$$
\begin{gathered}
y=y_{0}+v_{\mathrm{a}} t^{2}-\frac{2 v_{\mathrm{a}}}{k_{*}} t+\frac{2 v_{\mathrm{a}}}{k_{*}^{2}}\left(1-e^{-k * t}\right) \\
y_{0} \approx 0 \text { at } t=0 \\
y=2 \frac{K_{3}}{k_{3}} \ln \left(\frac{[\mathrm{S}]_{0} \mathrm{e}^{[P] / K_{3}}}{[S]_{0}-[P]}\right) \\
v_{\mathrm{a}}=\frac{k_{2}\left[\mathrm{Sk}^{\mathrm{U}}-\mathrm{PgA}\right]_{\mathrm{total}}[\mathrm{Pg}]}{K_{2}\left(1+\frac{[\mathrm{S}]}{K_{4}}\right)+[\mathrm{Pg}]} \\
k_{*}=k_{+\mathrm{a} 1}[\mathrm{Pg}]+k_{-\mathrm{a} 1} \\
k_{*}=\frac{k_{+\mathrm{b} 1}[\mathrm{Pg}]}{K_{\mathrm{b} 1}+[\mathrm{Pg}]}+k_{-\mathrm{b} 1}
\end{gathered}
$$

The parameters of eq I ( $k *$ and $v_{\mathrm{a}}$ ) were calculated for different Pg concentrations, which provided their dependences on $[\mathrm{Pg}]$. The chart $k_{*}$ versus [Pg] would be either linear (eq IVa) or hyperbolic (eq IVb), depending on the model of $\mathrm{Pg}$ binding to $\mathrm{Sk}^{\mathrm{U}}$ (reaction 1a or $1 \mathrm{~b}$, respectively). The chart $v_{\mathrm{a}}$ versus $[\mathrm{Pg}]$ was fitted according to eq III to calculate coefficients of the $\mathrm{Sk}^{\mathrm{U}}-\mathrm{PgA}$-catalyzed reaction: $K_{2}{ }^{\text {app }}=$ $K_{2}\left(1+[\mathrm{S}] / K_{4}\right)$ and $k_{2}$.

Kinetic Analysis of Plasminogen Activation Mediated by $S k^{U}$ Fragments. The activity of the $\mathrm{Sk}^{\mathrm{U}}$ fragments generated by limited proteolysis could potentially follow the mechanism either identical to that of the full-length protein (model 1) or similar to that of staphylokinase. In the last case, the $\mathrm{Sk}^{\mathrm{U}}$ fragment of $\mathrm{N}$-residues $\left(\mathrm{Sk}^{\mathrm{N}}\right)$ binds to both $\mathrm{Pg}$ and $\mathrm{Pn}$, but only the $\mathrm{Sk}^{\mathrm{N}}-\mathrm{Pn}$ complex possesses $\mathrm{Pg}$-specific proteolytic activity. High concentration of $\mathrm{Sk}^{\mathrm{N}}$ in the reaction medium introduced several new elements when compared with model 1 . The process was described by a set of chemical reactions shown in the model below:

Model 2

$$
\begin{aligned}
& \mathrm{Sk}^{\mathrm{N}}+\mathrm{Pg} \underset{k_{5}}{\stackrel{\mathrm{Sk}^{\mathrm{N}}}{\rightleftarrows}} \mathrm{Pg}
\end{aligned}
$$

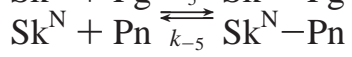

$$
\begin{aligned}
& \mathrm{Sk}^{\mathrm{N}}-\mathrm{Pn}+\mathrm{Pg} \stackrel{K_{6}}{\leftrightarrow} \mathrm{Sk}^{\mathrm{N}}-\mathrm{Pn}-\mathrm{Pg} \stackrel{k_{6}}{\longrightarrow} \mathrm{Sk}^{\mathrm{N}}-\mathrm{Pn}+\mathrm{Pn} \\
& \mathrm{Pn}+\mathrm{S} \stackrel{K_{7}}{\Leftrightarrow} \mathrm{Pn}-\mathrm{S} \stackrel{k_{7}}{\longrightarrow} \mathrm{Pn}+\mathrm{P} \\
& \mathrm{Sk}^{\mathrm{N}}-\mathrm{Pn}+\mathrm{S} \stackrel{K_{8}}{\Leftrightarrow} \mathrm{Sk}^{\mathrm{N}}-\mathrm{Pn}-\mathrm{S} \stackrel{k_{8}}{\longrightarrow} \mathrm{Sk}^{\mathrm{N}}-\mathrm{Pn}+\mathrm{P} \\
& \mathrm{Sk}^{\mathrm{N}}-\mathrm{Pn}+\mathrm{Sk}^{\mathrm{N}}-\mathrm{Pg} \stackrel{K_{9}}{\leftrightarrow} \mathrm{Sk}^{\mathrm{N}}-\mathrm{Pn}-\mathrm{Pg}-\mathrm{Sk}^{\mathrm{N}} \stackrel{k_{9}}{\rightarrow} \\
& \mathrm{Sk}^{\mathrm{N}}-\mathrm{Pn}+\mathrm{Sk}^{\mathrm{N}}-\mathrm{Pn}
\end{aligned}
$$

Reaction 5 depicts two binding reactions with identical parameters: association of $\mathrm{Sk}^{\mathrm{N}}$ with either $\mathrm{Pg}$ or Pn. Reaction 7 is, actually, identical to reaction 3 in model 1, except for the temperature of the reaction $\left(20^{\circ} \mathrm{C}\right)$, and $K_{7}=200 \mu \mathrm{M}$ and $k_{7}=400 \mathrm{~min}^{-1}$. The amidase activity of the $\mathrm{Sk}^{\mathrm{N}}-\mathrm{Pn}$ complex is shown in reaction 8 , and $\mathrm{d}[\mathrm{P}] / \mathrm{d} t$ in this reaction has to be taken into account because of the high $\mathrm{Sk}^{\mathrm{N}}$ concentration under the conditions of the experiment. One can expect $K_{8} \approx K_{7}$ and $k_{8} \approx k_{7}$. The potential activity of $\mathrm{Sk}^{\mathrm{N}}-\mathrm{Pn}$ toward $\mathrm{Sk}^{\mathrm{N}}-\mathrm{Pg}$ (reaction 9) should be considered under conditions of $\left[\mathrm{Sk}^{\mathrm{N}}\right] \gg[\mathrm{Pg}]$.

The designed model has no algebraic solution resulting in the equation $[\mathrm{P}]=f_{(t)}$. Instead, the appearance of $\mathrm{P}$ was simulated on a computer using the program Gepasi (2l) with the assigned set of initial concentrations and the kinetic parameters either determined in a separate reaction (line 7) or chosen by trial and error during fitting of the simulated curves to the experimental points; see the Results.

\section{RESULTS}

Expression and Structural Characterization of $S k^{U}$ and the $S k^{U}-P g$ Complex. The recombinant $\mathrm{Sk}^{\mathrm{U}}$ was expressed as a fusion protein with an $\mathrm{N}$-terminal $\mathrm{His}_{6}$-tag followed by a factor Xa cleavage site. The yield of recombinant $\mathrm{His}_{6}-\mathrm{Sk}^{\mathrm{U}}$ was $30 \mathrm{mg} / \mathrm{L}$ culture after purification. Treatment with factor $\mathrm{Xa}$ at $37^{\circ} \mathrm{C}$ at room temperature indicated a substantial nonspecific degradation of the protein. Digestion at $4{ }^{\circ} \mathrm{C}$ improved the specificity, and only minor degradation was observed under these conditions (Figure 1A).

Molecular masses of $\mathrm{Sk}^{\mathrm{U}}$ and $\mathrm{Sk}^{\mathrm{E}}$ (used as a reference) were estimated by gel filtration as 34 and $54 \mathrm{kDa}$, respectively, which agreed with the calculated values of 30.7 and $47 \mathrm{kDa}$ (Figure 2A). The monomeric nature of $\mathrm{Sk}^{\mathrm{U}}$ was confirmed by chemical cross-linking (data not shown). Formation of $\mathrm{Sk}^{\mathrm{U}}-\mathrm{bPg}$ and $\mathrm{Sk}^{\mathrm{E}}-\mathrm{hPg}$ complexes was demonstrated by SE-HPLC (Figure 2B,C). Thus, the elution peaks of the corresponding mixtures were shifted to higher molecular masses when compared with $\mathrm{bPg} / \mathrm{hPg}$ and $\mathrm{Sk}$ / $\mathrm{Sk}^{\mathrm{E}}$ (taken separately). SDS-PAGE analysis of a cross- 

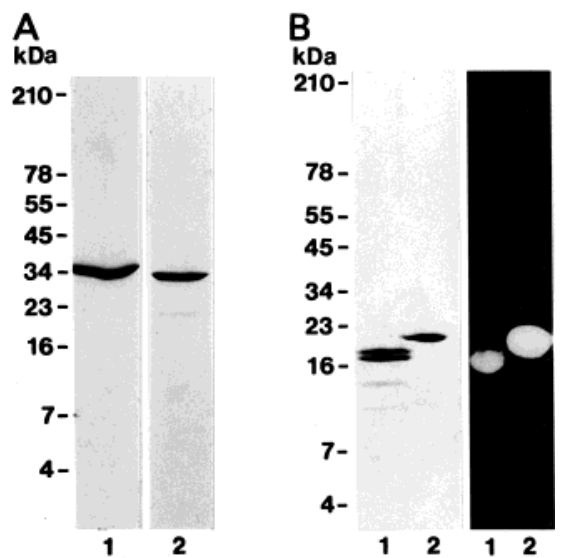

FIGURE 1: SDS-PAGE and zymography analysis of $\mathrm{Sk}^{\mathrm{U}}$ and enzymatic derived fragments. (A) SDS-PAGE of the recombinant protein $\mathrm{His}_{6}-\mathrm{Sk}^{\mathrm{U}}$ (lane 1) and the same protein after treatment with factor Xa (lane 2). (B) SDS-PAGE (left) and zymography analysis (right) of the purified chymotryptic fragments $\mathrm{Sk}^{\mathrm{U}, 123-261}$ (lane 1) and $\mathrm{Sk}^{\mathrm{U}, 97-261}$ (lane 2). The fragments were identified by the $\mathrm{N}$-terminal sequence. Molecular mass markers are indicated to the left in each panel.

linked preparation $\left(\mathrm{Sk}^{\mathrm{U}}\right.$ plus $\mathrm{bPg}$ ) as well as native PAGE of the same mixture also indicated formation of the $\mathrm{Sk}^{\mathrm{U}}$ bPg complex (data not shown). We could not detect binding of $\mathrm{Sk}^{\mathrm{U}}$ and $\mathrm{Sk}^{\mathrm{E}}$ to the "wrong" plasminogens (human and bovine, respectively) under the experimental conditions.

Kinetic Characterization of the $S k^{U}-P g A$-Catalyzed Plasminogen Activation. $\mathrm{Sk}^{\mathrm{U}}$ was able to react with bovine $\mathrm{Pg}$ and to a lower extent with equine or ovine Pg. The complex of $\mathrm{Sk}^{\mathrm{U}}$ with bovine $\mathrm{Pg}$ was able to activate $\mathrm{Pgs}$ from all tested sources (bovine, ovine, pig, equine, rabbit, and human), and the system $\mathrm{Sk}^{\mathrm{U}}$ plus bovine $\mathrm{Pg}$ was used in the following experiments. The rate coefficient $\left(k_{*}\right)$ of the prestationary phase and the activity $\left(v_{\mathrm{a}}\right)$ of $\mathrm{Sk}^{\mathrm{U}}-\mathrm{PgA}$ were calculated from the charts $y$ versus $t^{2}$ (Figure $3 \mathrm{~A}$ ) at different Pg concentrations according to model 1 . The appropriate fit of the experimental points testified for the validity of the chosen mechanism.

Analysis of the prestationary phase showed a Michaelislike dependence of $k_{*}$ on [Pg] (Figure 3B), which corresponded to the mechanism with an inactive intermediate (reaction $1 \mathrm{~b}$ and eq IVb). The dissociation constant of the inactive complex $\mathrm{Sk}^{\mathrm{U}}-\mathrm{Pg}$ was calculated as $K_{\mathrm{b} 1}=4.6 \mu \mathrm{M}$. Transition between the inactive intermediate $\mathrm{Sk}^{\mathrm{U}}-\mathrm{Pg}$ and the active complex $\mathrm{Sk}^{\mathrm{U}}-\mathrm{PgA}$ was described by the rate coefficients $k_{+\mathrm{b} 1}=17 \mathrm{~min}^{-1}$ (Figure 3B) and $k_{-\mathrm{b} 1}=0.11$ $\min ^{-1}$ (Figure 3C). The dissociation constant $\left(K_{\mathrm{d}}\right)$ of the activation complex $\mathrm{Sk}^{\mathrm{U}}-\mathrm{PgA}$ is then given by the equation $K_{\mathrm{d}}=K_{\mathrm{b} 1}\left(k_{-\mathrm{b} 1} / k_{+\mathrm{b} 1}\right)=30 \mathrm{nM}$.

The Pg-activating velocity (chart $v_{\mathrm{a}}$ versus $[\mathrm{Pg}]$ in Figure 3D) showed a Michaelis-like dependence with $K_{\mathrm{m}}^{\text {app }}=$ $K_{2}\left(1+[\mathrm{S}] / K_{4}\right)=1.5 \mu \mathrm{M}$ and $V_{\max }=0.033 \mu \mathrm{M} \mathrm{min} \min ^{-1}$ $\left(k_{\text {cat }}=33 \mathrm{~min}^{-1}\right)$. The real $K_{\mathrm{m}}$ value for $\mathrm{Sk}^{\mathrm{U}}-\mathrm{PgA}$-catalyzed $\mathrm{Pg}$ conversion (i.e., $\left.K_{2}\right)$ can be estimated from $K_{\mathrm{m}}$ app as $K_{2} \approx 0.4 \mu \mathrm{M}$ considering $K_{4} \approx K_{3}=200 \mu \mathrm{M}(19,20)$ and $[\mathrm{S}]=500 \mu \mathrm{M}$.

The mechanism, comprising both prestationary and stationary phases of $\mathrm{Sk}^{\mathrm{U}}$ action, can be summarized as follows:

$$
\begin{gathered}
\mathrm{Sk}^{\mathrm{U}}+\mathrm{Pg} \stackrel{4.6 \mu \mathrm{M}}{\Longleftrightarrow} \mathrm{Sk}^{\mathrm{U}}-\mathrm{Pg} \underset{0.11 \mathrm{~min}^{-1}}{\stackrel{17 \mathrm{~min}^{-1}}{\rightleftarrows}} \mathrm{Sk}^{\mathrm{U}}-\mathrm{PgA} \\
\mathrm{Sk}^{\mathrm{U}}-\mathrm{PgA}+\mathrm{Pg} \stackrel{\leq 1.5 \mu \mathrm{M}}{\Longleftrightarrow} \mathrm{Sk}^{\mathrm{U}}-\mathrm{PgA}-\mathrm{Pg} \frac{33.5 \mathrm{~min}^{-1}}{\mathrm{Sk}^{\mathrm{U}}-\mathrm{PgA}+\mathrm{Pn}}
\end{gathered}
$$

Short preincubation of $\mathrm{Sk}^{\mathrm{U}}$ and $\mathrm{Pg}\left(\left[\mathrm{Sk}^{\mathrm{U}}\right]>[\mathrm{Pg}]\right)$ abolished the lag phase (Table 1). Both amidase and proteinase activity of the $\mathrm{Sk}^{\mathrm{U}}-\mathrm{PgA}$ complex could be suppressed by $\alpha_{2}$-AP (Table 1 ) in contrast to the $\alpha_{2}$-APinsensitive $\mathrm{Sk}^{\mathrm{E}}$. Restoration of the proteinase activity after a 15 min lag was observed, when a mixture of $\mathrm{Sk}^{\mathrm{U}}+\mathrm{Pg}+$ $\alpha_{2}$-AP was added to the reaction medium with $\mathrm{Pg}$. The effect can be ascribed to gradual dissociation of the inactive $\mathrm{Sk}^{\mathrm{U}}-$ $\mathrm{Pg}-\alpha_{2}$-AP complexes and rebinding of $\mathrm{Sk}^{\mathrm{U}}$ to fresh $\mathrm{Pg}$. The presence of $\mathrm{Fb}$ or $\mathrm{CNBr}-\mathrm{Fb}$ fragments stimulated the activity of $\mathrm{Sk}^{\mathrm{U}}$, but only $\mathrm{Fb}$ made the initial lag phase disappear (Table 1).

Limited Proteolysis of $S k^{U}$. Limited proteolysis was carried out to confirm the anticipated domain structure of $\mathrm{Sk}^{\mathrm{U}}$ and, at the same time, generate fragments for functional analysis. Digestion with proteases generated stable N-terminal fragments of similar size, $11 \sim 120$ (elastase), 12 148 (trypsin), and 10 141 (chymotrypsin), and less stable C-terminal fragments $139-261,158-261,158-200$, and 201-261
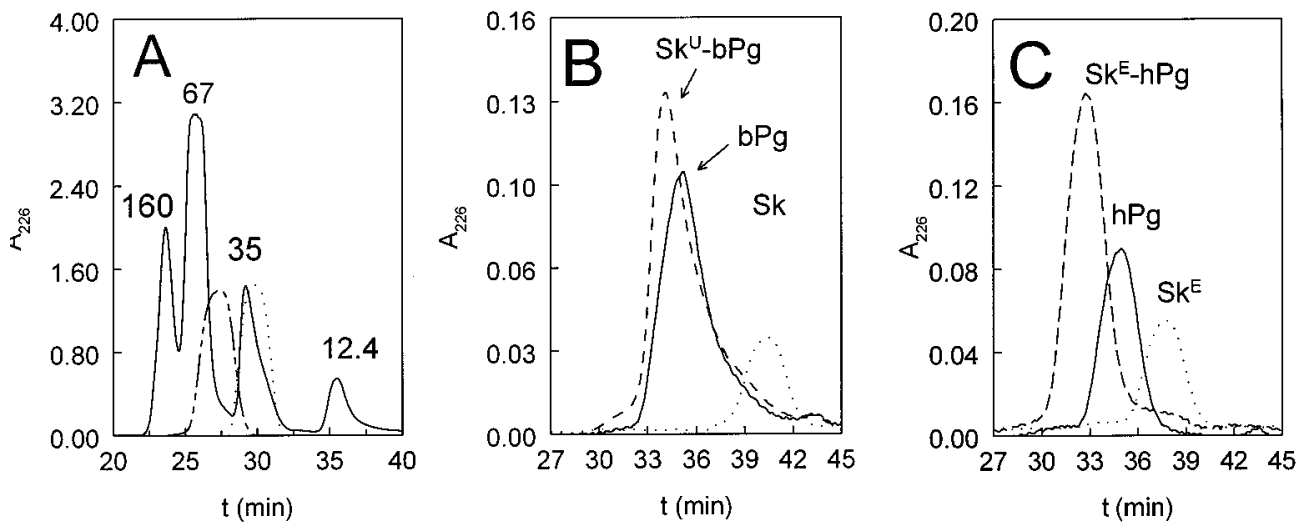

FIGURE 2: Estimation of molecular masses of the recombinant $\mathrm{Sk}^{\mathrm{U}}$ with a normal $\mathrm{N}$-terminus and the native $\mathrm{Sk}^{\mathrm{E}}$. Detection of $\mathrm{Sk} \mathrm{k}^{\mathrm{U}}-\mathrm{bPg}$ and $\mathrm{Sk}^{\mathrm{E}}-\mathrm{hPg}$ complexes. (A) The elution profile of the calibrating proteins is shown as a solid line, and the positions of $\mathrm{Sk}^{\mathrm{U}}$ and $\mathrm{Sk}^{\mathrm{E}}$ are indicated by dotted and broken lines, respectively. The molecular masses of the markers are shown in kilodaltons. (B) The elution profiles of the mixture $\mathrm{Sk}^{\mathrm{U}}$ plus bPg (broken line), and the same proteins taken separately: bPg (solid line), Sk ${ }^{\mathrm{U}}$ (dotted line). (C) The elution profiles of the mixture $\mathrm{Sk}^{\mathrm{E}}$ plus $\mathrm{hPg}$ (broken line), and the same proteins taken separately: $\mathrm{hPg}$ (solid line), $\mathrm{Sk}^{\mathrm{E}}$ (dotted line). 

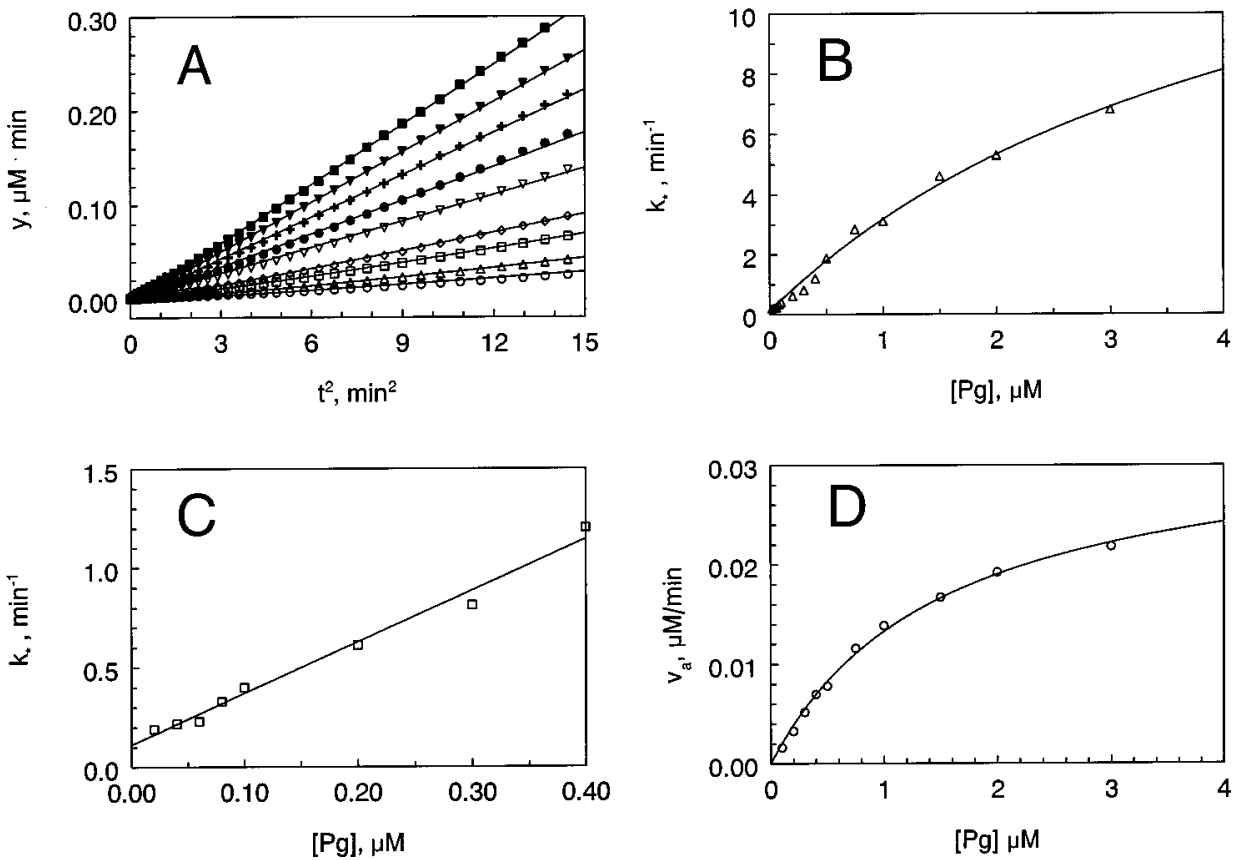

FIGURE 3: $\mathrm{Sk}^{\mathrm{U}}-\mathrm{PgA}$-mediated plasminogen activation $\left(37^{\circ} \mathrm{C}\right)$. (A) The reaction at $1 \mathrm{nM} \mathrm{Sk}^{\mathrm{U}}$ and $0.02-3.0 \mu \mathrm{M}$ Pg in the transformed coordinates $y$ versus $t^{2}$ (see eq II). The symbols $\bigcirc, \Delta, \square, \diamond, \nabla, \boldsymbol{\bullet},+, \boldsymbol{\nabla}$, and $\mathbf{\square}$ correspond to $[\mathrm{Pg}](\mu \mathrm{M}): 0.2,0.3,0.4,0.5,0.75,1.0,1.5$, 2.0, and 3.0, respectively. Solid lines show the best fit according to eq I and model 1. (B) Analysis of the rate coefficient $k *$ of the prestationary phase. The $k_{*}$ values at different concentrations of Pg were calculated from the curves in panel A. The dependence of $k_{*}$ on [Pg] was fitted by eq IVb with $K_{\mathrm{b} 1}=4.6 \mu \mathrm{M}$ and $k_{+\mathrm{b} 1}=17 \mathrm{~min}^{-1}$. (C) Estimation of $k_{-\mathrm{b} 1}$ in eq IVb by linear regression analysis of $k_{*}$ values at low [Pg] $(0.02-0.4 \mu \mathrm{M}), k_{-\mathrm{b} 1}=0.11 \mathrm{~min}^{-1}$. (D) Analysis of the Pg-activating velocity $\left(v_{\mathrm{a}}\right)$ in the stationary phase of the reaction. The $v_{\mathrm{a}}$ values were calculated from the curves in panel A. The dependence of $v_{\mathrm{a}}$ on $[\mathrm{Pg}]$ was fitted by eq III (Michaelis equation) with $K_{\mathrm{m}}$ app $=1.5 \mu \mathrm{M}$

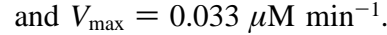

\begin{tabular}{|c|c|c|c|c|c|c|}
\hline \multirow{2}{*}{$\begin{array}{c}\text { reagents } \\
\text { (preincubated reagents are underlined) }\end{array}$} & \multirow{2}{*}{$\begin{array}{c}\text { ratio, } \mathrm{nM} \\
\text { (amidase activity) }\end{array}$} & \multirow{2}{*}{$\begin{array}{c}\text { ratio, } \mathrm{nM} \\
\text { (Pg activation) }\end{array}$} & \multicolumn{2}{|c|}{ amidase activity } & \multicolumn{2}{|c|}{ Pg activation } \\
\hline & & & lag, min & s. slope, ${ }^{b} \%$ & lag, min & s, slope, $\%$ \\
\hline $\mathrm{Sk}^{\mathrm{U}}+\mathrm{Pg}$ & 200:100 & $1: 100$ & 5 & 100 & 5 & 100 \\
\hline $\mathrm{Sk}^{\mathrm{U}}+\mathrm{Pg}$ & 200:100 & $1: 100$ & 0 & 100 & 0 & 100 \\
\hline $\mathrm{Sk}^{\mathrm{U}}+\mathrm{Pg}+\alpha_{2}-\mathrm{AP}$ & 200:100:300 & $\mathrm{na}^{c}$ & 0 & 2 & na & na \\
\hline $\mathrm{Pg}+\mathrm{Sk}^{\mathrm{U}}+\mathrm{Pg}+\alpha_{2}-\mathrm{AP}$ & na & $100: 0.5: 0.5: 1.5$ & na & na & 15 & 90 \\
\hline $\mathrm{Sk}^{\mathrm{U}}+\mathrm{Pg}+\alpha_{2}-\mathrm{AP}$ & 200:100:1 & $1: 100: 1$ & 5 & 100 & 5 & 100 \\
\hline $\mathrm{Sk}^{\mathrm{U}}+\overline{\mathrm{Pg}+\mathrm{Fb}}$ & $\mathrm{nd}^{d}$ & 1:100:200 & nd & nd & 0 & 300 \\
\hline $\mathrm{Sk}^{\mathrm{U}}+\mathrm{Pg}+\mathrm{CNBr} \mathrm{Fb}$ & nd & $1: 100: 200$ & nd & nd & 5 & 600 \\
\hline $\mathrm{Sk}^{\mathrm{U}}+\overline{\mathrm{Pg}+\mathrm{Sk}^{\mathrm{U}, \sim 1 \sim 140}}$ & nd & 1:100:200 & nd & nd & 5 & 100 \\
\hline $\mathrm{Sk}^{\mathrm{U}}+\widetilde{\mathrm{Pg}+\mathrm{Sk}^{\mathrm{U}, \sim 140 \sim 2}} 61$ & nd & 1:100:200 & nd & nd & 5 & 100 \\
\hline $\mathrm{Sk}^{\mathrm{U}}+\widetilde{\mathrm{Pg}+\mathrm{Sk}^{\mathrm{U}, 123-261}}$ & nd & 1:100:200 & nd & nd & 40 & 60 \\
\hline $\mathrm{Sk}^{\mathrm{U}}+\widetilde{\mathrm{Pg}+\mathrm{Sk}^{\mathrm{U}, 97-261}}$ & nd & $1: 100: 200$ & nd & nd & 60 & 30 \\
\hline
\end{tabular}

${ }^{a}$ The amidase reaction was analyzed in the coordinates [P] (concentration of $p$-nitroaniline) versus $t$, and the lag time was determined as the intersection of the linear phase with the $t$-axis. The Pg activating reaction was analyzed in coordinates $y$ (see eq II) versus $t^{2}$, and the lag was determined as the square root of the intersection of the linear phase with the $t^{2}$-axis. (See the Materials and Methods for further experimental details.) ${ }^{b}$ s. slope $=$ stationary slope. ${ }^{c}$ na $=$ not applicable. ${ }^{d}$ nd $=$ not determined.

(elastase) and 97-261 and 123-261 (chymotrypsin). These data are in agreement with the proposed structure of $\mathrm{Sk}^{\mathrm{U}}$ (13) comprising one $\mathrm{N}$-terminal domain $(1-125)$ and one C-terminal domain $(126-261)$ corresponding to $\alpha$ - and $\beta$-domains of $\mathrm{Sk}^{\mathrm{E}}(7,22)$.

Kinetic Characterization of the Activity of $S k^{U}$ Fragments. Zymographic and kinetic analysis of several fragments generated by limited proteolysis indicated that only $\mathrm{Sk}^{\mathrm{U}, 97-261}$ and $\mathrm{Sk}^{\mathrm{U}, 123-261}$ had the ability to activate $\mathrm{Pg}$ (Figure $1 \mathrm{~B}$ ). None of the inactive fragments interfered with Pg activation as followed from the absence of any effect on the concamitant $\mathrm{Sk}^{\mathrm{U}}$-mediated $\mathrm{Pg}$ activation (Table 1). Only Sk $\mathrm{Sk}^{\mathrm{U}, 97-261}$ and $\mathrm{Sk}^{\mathrm{U}, 123-261}$ were able to inhibit the reaction, presumably due to competition between these fragments and $\mathrm{Sk}^{\mathrm{U}}$ for the same binding site on Pg (Table 1). The inhibiting effect was expressed as a 40-60 min lag before gradual restoration of some catalytic activity. A mixture of the inactive fragments that generally reconstituted the full-length sequence of $\mathrm{Sk}^{\mathrm{U}}$ had no activity.

Preliminary kinetic experiments in the coupled reaction mixture with the C-terminal fragments $\left(\mathrm{Sk}^{\mathrm{U}, 97-261}\right.$ or $\left.\mathrm{Sk}^{\mathrm{U}, 123-261}\right)$ showed a qualitatively similar behavior, but with $\mathrm{Sk}^{\mathrm{U}, 97-261}$ being 2-3 times more effective. Therefore, the subsequent experiments were carried out with the more active moiety (Figure 4). As the first step, the process of Pg activation and accompanying liberation of $p$-nitroaniline was followed at different $\mathrm{Sk}^{\mathrm{U}, 97-261}$ concentrations $(0-0.8 \mu \mathrm{M})$ (Figure 4A). Initial fit according to model 1 and eq I revealed an 

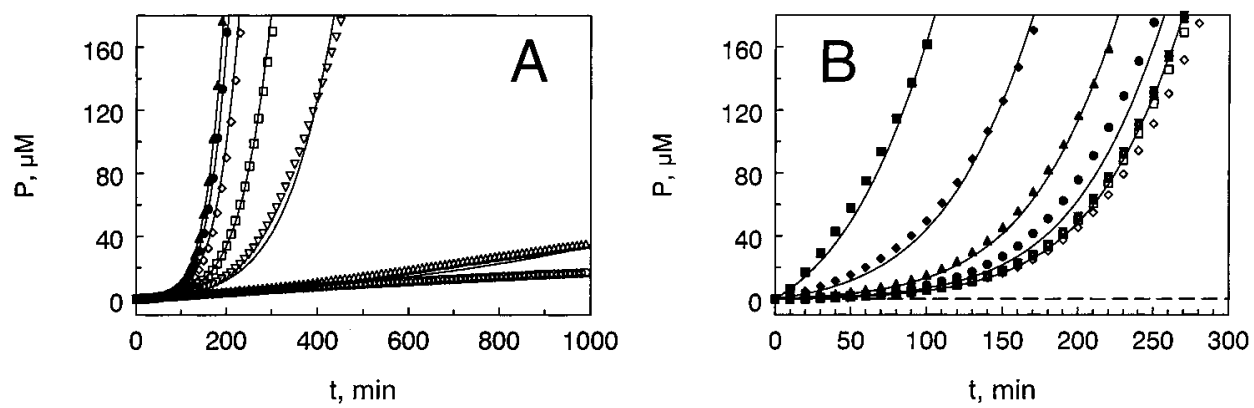

FIGURE 4: $\mathrm{Sk}^{\mathrm{U}, 97-261}-\mathrm{Pn}$-mediated plasminogen activation $\left(20{ }^{\circ} \mathrm{C}\right)$. Release of $p$-nitroaniline $(\mathrm{P})$ was followed in time in the reaction medium containing $\mathrm{Sk}^{\mathrm{U}}, 97-261$, Pn (endogenous or added), and Pg. Solid lines show the best fit according to model 2. (A) The reaction was carried out with $0.1 \mu \mathrm{MPg}$ (containing background Pn) and various concentrations of $\mathrm{Sk}^{\mathrm{U}, 97-261}$. The symbols $\bigcirc, \Delta, \nabla, \square, \diamond, \boldsymbol{\bullet}$, and $\mathbf{\square}$ correspond to $\left[\mathrm{Sk}^{\mathrm{U}, 97-261}\right](\mu \mathrm{M}): 0,0.01,0.1,0.2,0.4,0.6$, and 0.8 , respectively. (B) The reaction was carried out with $0.1 \mu \mathrm{M}$ Pg, 0.25 $\mu \mathrm{M} \mathrm{Sk}^{\mathrm{U}, 97-261}$ and various concentrations of added Pn. The symbols $\bigcirc, \Delta, \nabla, \square, \diamond, \boldsymbol{Q}, \boldsymbol{\Delta}, \boldsymbol{\nabla}$, and $\mathbf{\square}$ correspond to the added [Pn] (pM): $0,0.02,0.1,0.5,3,16,80,400$, and 2000, respectively (background $[\mathrm{Pn}]=50 \mathrm{pM}$ ). The dashed line corresponds to the reaction of $\mathrm{Sk}^{\mathrm{U}, 97-261}$ with Pn-depleted preparation of $\mathrm{Pg}\left(\mathrm{Pg}+\alpha_{2}-\mathrm{AP}, 100: 1\right)$.

unsatisfactory description of the experimental points (not shown).

An analogous experiment was carried out at constant concentrations of $\mathrm{Sk}^{\mathrm{U}, 97-261}$ and $\mathrm{Pg}$, but with different amounts of added Pn (0-2 nM) (Figure 4B). The effect became visible at $[\mathrm{Pn}]>10 \mathrm{pM}$, which suggested that the concentration of endogenous $\mathrm{Pn}$ in the Pg preparation was $50-100 \mathrm{pM}$. When the activity of endogenous Pn in the Pg preparation was suppressed by preincubation with $\alpha_{2}$-AP, the fragment was incapable of $\mathrm{Pg}$ activation. The best fit according to model 1 provided an inadequate description of the experimental points (not shown).

The resulting simulations of the $\mathrm{Sk}^{\mathrm{U}, 97-261}$-catalyzed $\mathrm{Pg}$ activation, depicted as charts [P] versus $t$, were performed on the basis of model 2 (Figure 4, solid lines). The concentrations of $\mathrm{Sk}^{\mathrm{U}, 97-261}, \mathrm{Pg}$, and $\mathrm{S}$ were assumed to be close to the initial values during the reaction time. The endogenous $\mathrm{Pn}$ concentration was assigned to $50 \mathrm{pM}$ as estimated in the above paragraph. The reactions were presented as simple bimolecular processes with the apparent rate coefficients $k_{\text {app }}$ chosen by trial and error except for the measured constants of Pn-catalyzed consumption of S.

$$
\begin{aligned}
& \mathrm{Sk}^{\mathrm{N}}+\mathrm{Pg} \underset{\geq 1 \mu \mathrm{M}^{-1} \min ^{-1}}{\longrightarrow} \mathrm{Sk}^{\mathrm{N}}-\mathrm{Pg} \\
& \mathrm{Sk}^{\mathrm{N}}+\mathrm{Pn} \underset{\geq 0.16 \mathrm{~min}^{-1}}{\rightleftarrows} \mathrm{Sk}^{\mathrm{N}}-\mathrm{Pn} \\
& \mathrm{Sk}^{\mathrm{N}}-\mathrm{Pn}+\mathrm{Pg} \stackrel{k_{\text {app } 69}=0.4 \mu \mathrm{M}^{-1} \mathrm{~min}^{-1}}{\longrightarrow} \mathrm{Sk}^{\mathrm{N}}-\mathrm{Pn}+\mathrm{Pn} \\
& \mathrm{Sk}^{\mathrm{N}}-\mathrm{Pn}+\mathrm{Sk}^{\mathrm{N}}-\mathrm{Pg} \longrightarrow \mathrm{Sk}^{\mathrm{N}}-\mathrm{Pn}+\mathrm{Sk}^{\mathrm{N}}-\mathrm{Pn} \\
& k_{\text {app69 }}=\frac{k_{6}}{K_{6}\left(1+\frac{[\mathrm{S}]}{K_{8}}+\frac{\left[\mathrm{Sk}^{\mathrm{N}}-\mathrm{Pg}\right]}{K_{9}}\right)+[\mathrm{Pg}]}= \\
& \frac{k_{9}}{K_{9}\left(1+\frac{[\mathrm{S}]}{K_{8}}+\frac{[\mathrm{Pg}]}{K_{6}}\right)+\left[\mathrm{Sk}^{\mathrm{N}}-\mathrm{Pg}\right]} \\
& \mathrm{Pn}+\mathrm{S} \stackrel{k_{\mathrm{app} 78}=0.6 \mu \mathrm{M}^{-1} \mathrm{~min}^{-1}}{\longrightarrow} \mathrm{Pn}+\mathrm{P} \\
& \mathrm{Sk}^{\mathrm{N}}-\mathrm{Pn}+\mathrm{S} \longrightarrow \mathrm{Sk}^{\mathrm{N}}-\mathrm{Pn}+\mathrm{P} \\
& k_{\text {app } 78}=\frac{k_{7}}{K_{7}+[\mathrm{S}]}=\frac{k_{8}}{K_{8}\left(1+\frac{[\mathrm{Pg}]}{K_{6}}+\frac{\left[\mathrm{Sk}^{\mathrm{N}}-\mathrm{Pg}\right]}{K_{9}}\right)+[\mathrm{S}]}
\end{aligned}
$$

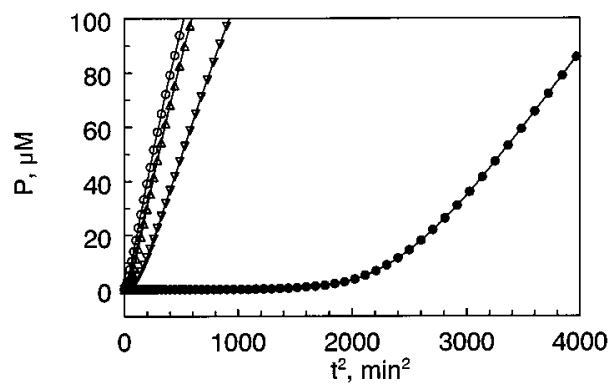

FIGURE 5: $\mathrm{His}_{6}-\mathrm{Sk}^{\mathrm{U}}$-mediated plasminogen activation $\left(20^{\circ} \mathrm{C}\right)$. The concentration of the liberated $p$-nitroaniline is depicted as a function of $t^{2}$. The reactions were carried out with $0.1 \mu \mathrm{M} \mathrm{Pg}$ (containing background $\mathrm{Pn}$ ) or a Pn-depleted preparation of $\mathrm{Pg}\left(\mathrm{Pg}+\alpha_{2}\right.$-AP, 100:1) and $1 \mathrm{nM} \mathrm{His}_{6}-\mathrm{Sk}^{\mathrm{U}}$ or $1 \mathrm{nM} \mathrm{Sk}^{\mathrm{U}}$. Components of the mixture: $(\bigcirc) \mathrm{Pg}$ and $\mathrm{Sk}^{\mathrm{U}},(\triangle) \mathrm{Pg}-\alpha_{2}-\mathrm{AP}$ and $\mathrm{Sk}^{\mathrm{U}},(\nabla) \mathrm{Pg}$ and $\mathrm{His}_{6}-\mathrm{Sk}^{\mathrm{U}},(\bullet) \mathrm{Pg}-\alpha_{2}-\mathrm{AP}$ and $\mathrm{His}_{6}-\mathrm{Sk}^{\mathrm{U}}$.

The first reaction defines equilibrium dissociation constants of the complexes $\mathrm{Sk}^{\mathrm{U}, 97-261}-\mathrm{Pg}$ and $\mathrm{Sk}^{\mathrm{U}, 97-261}-\mathrm{Pn}$ as $K_{\mathrm{d}}=$ $0.16 \mu \mathrm{M}$ where any rate constants above the shown limits are suitable if they correspond to the established ratio. The individual constants of the three catalytic reactions involving $\mathrm{Sk}^{\mathrm{U}, 97-261}-\mathrm{Pn}$ were not determined; still, some reasonable assumptions could be drawn from the equivalence of the shown $k_{\text {app }}$ in eqs V and VI related to the reactions 6 and 9 and 7 and 8 in model 2, respectively. Thus, the equivalence of $K_{6}=K_{9}$ and $k_{6}=k_{9}$ follows from eq V. Equal catalytic efficiencies of $\mathrm{Pn}$ and $\mathrm{Sk}^{\mathrm{U}, 97-261}-\mathrm{Pn}$ toward $\mathrm{S}$ testify for $K_{6}$, $K_{9} \gg[\mathrm{Pg}]_{\text {total }}=0.1 \mu \mathrm{M}, K_{8}=K_{7}=200 \mu \mathrm{M}$, and $k_{8}=k_{7}=$ $400 \mathrm{~min}^{-1}$ (eq VI). Under these circumstances, $k_{\text {app }}$ of $\mathrm{Sk}^{\mathrm{U}, 97-261}-\mathrm{Pn}$-catalyzed conversion of $\mathrm{Pg}$ (or $\mathrm{Sk}^{\mathrm{U}, 97-261}-$ $\mathrm{Pg}$ ) becomes equal to $k_{6} /\left(3.5 K_{6}\right)=0.4 \mu \mathrm{M}^{-1} \mathrm{~min}^{-1}$ and $k_{6} /$ $K_{6}=1.4 \mu \mathrm{M}^{-1} \min ^{-1}\left(20^{\circ} \mathrm{C}\right)$. The analogous parameter for the catalytic complex with the full-length activator $\left(\mathrm{Sk}^{\mathrm{U}}-\right.$ $\mathrm{PgA})$ was estimated as $k_{2} / K_{2} \approx 25 \mu \mathrm{M}^{-1} \min \left(20^{\circ} \mathrm{C}\right)$.

Catalytic Activity of $\mathrm{His}_{6}-\mathrm{Sk}^{U}$. The reaction with $\mathrm{His}_{6}-$ $\mathrm{Sk}^{\mathrm{U}}$ was characterized by a prolonged lag phase which became particularly pronounced when the Pg preparation was depleted of endogenous Pn activity by preincubation with $\alpha_{2}$-AP at the ratio Pg: $\alpha_{2}=100: 1$ (Figure 5). Gradual restoration of the activity after $\alpha_{2}$-AP treatment is likely to be caused by some small amounts of active Pn, sufficient to ignite the "chain reaction" after a substantial delay. In agreement with this observation, we found that addition of Pn shortened the lag phase (data not shown). The presence of $\alpha_{2}$-AP had no effect on the reaction mediated by $\mathrm{Sk}^{\mathrm{U}}$ under 


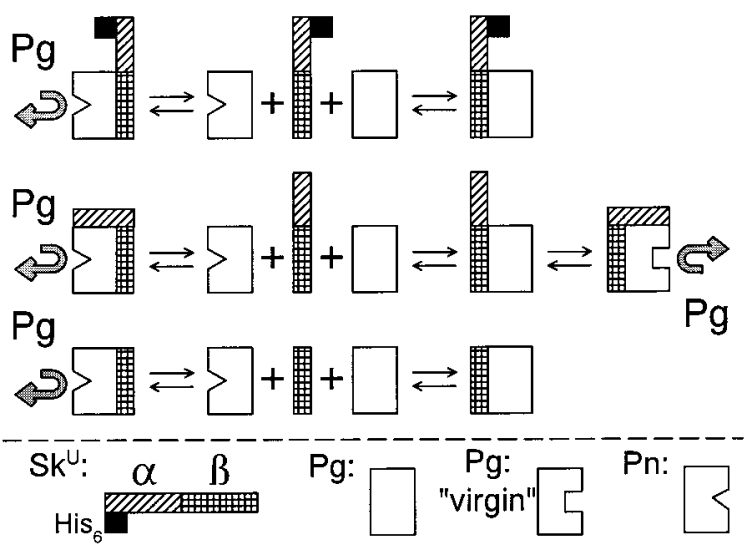

FIGURE 6: Schematic presentation of the Pg activating reaction mediated by native $\mathrm{Sk}^{\mathrm{U}}, \mathrm{His}_{6}-\mathrm{Sk}^{\mathrm{U}}$, and $\mathrm{Sk}^{\mathrm{U}, 97-261}$. Only native $\mathrm{Sk}^{\mathrm{U}}$ is able to catalyze the conformational change in the serine protease domain of $\mathrm{Pg}$, resulting in the active $\mathrm{Sk}^{\mathrm{U}}-\mathrm{Pg}$ activator complex. $\mathrm{His}_{6}-\mathrm{Sk}^{\mathrm{U}}$ and $\mathrm{Sk}^{\mathrm{U}, 97-261}$ only form activator complexes with $\mathrm{Pn}$. The twisted arrows indicate the ability of the formed activator complexes to perform Pg activation.

analogous conditions. These data argue for the N-terminalmodified protein $\left(\mathrm{His}_{6}-\mathrm{Sk}^{\mathrm{U}}\right)$ being active only in complex with $\mathrm{Pn}$, while the zymogen complex $\mathrm{His}_{6}-\mathrm{Sk}^{\mathrm{U}}-\mathrm{Pg}$ either is completely inert or has a very low activity.

\section{DISCUSSION}

In the present work we have investigated Pg-activating reactions catalyzed by the full-length recombinant $\mathrm{Sk}^{\mathrm{U}}(\alpha, \beta$ domains), the $\mathrm{C}$-terminal fragment $\mathrm{Sk}^{\mathrm{U}, 97-261}$ ( $\beta$-domain), or the protein with an $\mathrm{N}$-terminal tag, $\mathrm{His}_{6}-\mathrm{Sk}^{\mathrm{U}}$ (modified $\alpha, \beta$ ).

$\mathrm{Sk}^{\mathrm{U}}$-induced activation of bovine $\mathrm{Pg}$ was characterized by the presence of a prestationary lag phase. Kinetic analysis revealed a two-step mechanism of binding between $\mathrm{Sk}^{\mathrm{U}}$ and $\mathrm{Pg}$. Formation of an initially inactive $\mathrm{Sk}^{\mathrm{U}}-\mathrm{Pg}$ complex with the dissociation constant $K_{\mathrm{b} 1}=4.6 \mu \mathrm{M}$ was followed by transition to the catalytic complex $\mathrm{Sk}^{\mathrm{U}}-\mathrm{PgA}: k_{+\mathrm{b} 1}=17$ $\min ^{-1}, k_{-\mathrm{b} 1}=0.11 \mathrm{~min}^{-1}$ (see model 1). A similar two-step mechanism has also been observed for $\mathrm{Sk}^{\mathrm{E}}$-mediated $\mathrm{Pg}$ activation, where interaction between $\mathrm{Sk}^{\mathrm{E}}$ and $\mathrm{hPg}$ showed a temperature-dependent transition from an inactive complex to the active one (23). The dissociation constant of the catalytically potent complex $\mathrm{Sk}^{\mathrm{U}}-\mathrm{PgA}$ was equal to $K_{\mathrm{d}}=$ $K_{\mathrm{b} 1}\left(k_{+\mathrm{b} 1} / k_{-\mathrm{b} 1}\right)=30 \mathrm{nM}$, and this value is higher than the constants reported for $\mathrm{Sk}^{\mathrm{E}}$ and $\mathrm{Sak}$ bound to $\mathrm{Pg} / \mathrm{Pn}: K_{\mathrm{d}}=$ 1-2 $\mathrm{nM}(24,25)$. Lower affinity of $\mathrm{Sk}^{\mathrm{U}}$ toward $\mathrm{Pg}$ in comparison with $\mathrm{Sk}^{\mathrm{E}}$ may potentially be ascribed to lack of the $\gamma$-domain in the $\mathrm{Sk}^{\mathrm{U}}$ protein (13).

The parameters of the $\mathrm{Sk}^{\mathrm{U}}-\mathrm{PgA}$-catalyzed reaction $(\mathrm{Pg}$ $\rightarrow \mathrm{Pn}, 37^{\circ} \mathrm{C}$ ) were estimated as $K_{\mathrm{m}} \leq 1.5 \mu \mathrm{M}$ (presumably, $K_{\mathrm{m}} \approx 0.4 \mu \mathrm{M}$ because $K_{4} \approx K_{3}$, model 1$), k_{\text {cat }}=33 \mathrm{~min}^{-1}$, and $k_{\mathrm{cat}} / K_{\mathrm{m}} \approx 80 \mu \mathrm{M}^{-1} \min ^{-1}\left(k_{\mathrm{cat}} / K_{\mathrm{m}} \approx 25 \mu \mathrm{M}^{-1} \mathrm{~min}^{-1}\right.$ at $20^{\circ} \mathrm{C}$ ). The earlier obtained parameters of the $\mathrm{Sk}^{\mathrm{E}}$-mediated reaction $(19,26,27)$ varied in the range $K_{\mathrm{m}}=0.12-0.4$ $\mu \mathrm{M}$ and $k_{\mathrm{cat}}=7-140 \mathrm{~min}^{-1}$. The same constants of SakPn catalysis have been reported to be $K_{\mathrm{m}}=2.4-6.1 \mu \mathrm{M}$ and $k_{\text {cat }}=6-110 \mathrm{~min}^{-1}(28,29)$. The absence of the $\gamma$-domain in $\mathrm{Sk}^{\mathrm{U}}$ did not seem to alter the catalytic properties of its active complex with Pg when compared with the three$\alpha, \beta, \gamma$-domain $\mathrm{Sk}^{\mathrm{E}}$.

$\mathrm{Sk}^{\mathrm{U}}$ showed specificity toward bovine, equine, and ovine $\mathrm{Pg}$ in agreement with earlier observations (30), and the $\mathrm{Sk}^{\mathrm{U}}-$
Pg complex was able to activate all tested Pgs. This indicates that $\mathrm{Sk}^{\mathrm{U}}$ is highly specific during formation of the activator complex, but relatively nonspecific in activation of Pgs from different sources. Analogous observations have been made for different Pg complexes with $\mathrm{Sk}^{\mathrm{E}}$ (31). The excess of the physiological inhibitor of $\mathrm{Pn}\left(\alpha_{2}-\mathrm{AP}\right)$ inactivated the $\mathrm{Sk}^{\mathrm{U}}-$ Pg complex (this work) as well as Sak-Pn (32). On the contrary, no effect of $\alpha_{2}$-AP on the activity of $\mathrm{Sk}^{\mathrm{E}}-\mathrm{Pg}$ has been reported (33).

A two-domain structure of $\mathrm{Sk}^{\mathrm{U}}$ comprising an $\alpha$-domain from 1 to $125\left(1-146\right.$ in $\left.\mathrm{Sk}^{\mathrm{E}}\right)$ and a $\beta$-domain from 126 to $261\left(147-283\right.$ in $\left.\mathrm{Sk}^{\mathrm{E}}\right)$ was suggested from the data of limited proteolysis (this work) and from alignment with $\mathrm{Sk}^{\mathrm{E}}$ (13). When the proteolytic fragments of $\mathrm{Sk}^{\mathrm{U}}$ (containing either the $\mathrm{N}$-terminal $\alpha$-domain or the $\mathrm{C}$-terminal $\beta$-domain) were tested for potential activity, only two C-terminal fragments, $\mathrm{Sk}^{\mathrm{U}, 97-261}$ and $\mathrm{Sk}^{\mathrm{U}, 123-261}$, revealed Pg-activating ability of similar character.

The catalytic process mediated by the more potent fragment $\mathrm{Sk}^{\mathrm{U}, 97-261}$ was investigated in detail. The absence of $96 \mathrm{~N}$-terminal residues did not inflict critical damage on either complex formation of $\mathrm{Sk}^{\mathrm{U}, 97-261}-\mathrm{Pn} / \mathrm{Pg}$ or catalytic properties of $\mathrm{Sk}^{\mathrm{U}, 97-261}-\mathrm{Pn}$ when compared to $\mathrm{Sk}^{\mathrm{U}}-\mathrm{PgA}$ : (1) the affinity of the fragment to $\mathrm{Pn} / \mathrm{Pg}$ decreased 5 times $\left(K_{\mathrm{d}}=160 \mathrm{nM}\right)$; (2) the catalytic coefficient of the complex $\left(k_{\text {cat }} / K_{\mathrm{m}}=1.4 \mu \mathrm{M}^{-1} \mathrm{~min}^{-1}\right.$ at $20^{\circ} \mathrm{C}$ ) decreased $15-20$ times, which can be interpreted, for instance, as 4-fold increased $K_{\mathrm{m}}$ supplemented by 4 -fold decreased $k_{\text {cat. }}$. The crucial effect of the N-terminal truncation was, however, expressed as abolished virgin activity of the $\mathrm{Sk}^{\mathrm{U}, 97-261}-\mathrm{Pg}$ complex. The fragment was completely incapable of rendering Pg activation in the absence of some trace amounts of Pn, which was proven by use of an $\alpha_{2}$-AP-treated preparation of Pg. On the other hand, even negligible amounts of $\mathrm{Sk}^{\mathrm{U}, 97-261}-\mathrm{Pn}$ stimulated not only conversion of Pg to Pn but also the proteolytic activation of the inert complex $\mathrm{Sk}^{\mathrm{U}, 97-261}-\mathrm{Pg}$ as was shown by the effective reaction at $\left[\mathrm{Sk}^{\mathrm{U}, 97-261}\right] \gg[\mathrm{Pg}]$. The global fit of the experimental points according to the discussed mechanism (model 2) gave satisfactory results (Figure 4).

The possible participation of the native N-terminus of $\mathrm{Sk}^{\mathrm{U}}$ in the process of virgin activation of Pg was assessed by analyzing the kinetic behavior of the fusion protein $\mathrm{His}_{6}-$ $\mathrm{Sk}^{\mathrm{U}}$ (full-length $\mathrm{Sk}^{\mathrm{U}}$ modified by a small $\mathrm{N}$-terminal tag). This $\alpha$-domain modified activator was unable to produce the active complex with $\mathrm{Pg}$ as noticed when the Pn-depleted preparation of Pg was used (Figure 5). At the same time, $\mathrm{Sk}^{\mathrm{U}}$ without tag-activated $\alpha_{2}$-AP treated $\mathrm{Pg}$ as good as the original preparation. These facts testify for an important role of the $\alpha$-domain and particularly its $\mathrm{N}$-terminus during the virgin activation of $\mathrm{Pg}$ in accordance with the molecular sexuality hypothesis (34). Taken together, these data indicate that the induction of virgin activity in $\mathrm{Pg}$ is a consequence of a constraint, imposed on the serine protease molecule by the two-domain $\mathrm{Sk}^{\mathrm{U}}$ or the three-domain $\mathrm{Sk}^{\mathrm{E}}$, that facilitates the transition of the protease domain into an active configuration upon insertion of the streptokinase $\mathrm{N}$-terminus.

The performed work allowed the differential roles of the two domains in $\mathrm{Sk}^{\mathrm{U}}$ to be elucidated. The $\mathrm{N}$-terminal domain of $\mathrm{Sk}^{\mathrm{U}}$ (corresponding to the $\alpha$-domain of $\mathrm{Sk}^{\mathrm{E}}$ ) was essential for transformation of the inactive complex $\mathrm{Sk}^{\mathrm{U}}-\mathrm{Pg}$ to the active $\mathrm{Sk}^{\mathrm{U}}-\mathrm{PgA}$. The $\mathrm{C}$-terminal domain of $\mathrm{Sk}^{\mathrm{U}}$ (corre- 
sponding to the $\beta$-domain of $\mathrm{Sk}^{\mathrm{E}}$ ) rendered binding to $\mathrm{Pg}$ / $\mathrm{Pn}$ and participated in the catalytic function of the $\mathrm{Sk}^{\mathrm{U}}-$ PgA complex. A similar function of the $\beta$-domain was suggested from experiments with $\beta$-domain-mutated $\mathrm{Sk}^{\mathrm{E}}$ (24). These findings are schematically outlined in Figure 6. In the top reaction, the inability/ability of $\mathrm{His}_{6}-\mathrm{Sk}^{\mathrm{U}}$ to form an activator complex with $\mathrm{Pg} / \mathrm{Pn}$ is illustrated. Likewise, in the middle reaction, the ability of native $\mathrm{Sk}^{\mathrm{U}}$ to form an activator complex with $\mathrm{Pg}$ as well as $\mathrm{Pn}$ is shown. Finally, in the bottom reaction, the inability/ability of the $\beta$-domain to form an activator complex with $\mathrm{Pg} / \mathrm{Pn}$ is indicated.

The absence of the $\gamma$-domain in $\mathrm{Sk}^{\mathrm{U}}$ (as compared to the three-domain $\mathrm{Sk}^{\mathrm{E}}$ ) might be a reason the $\mathrm{Sk}^{\mathrm{U}}-\mathrm{PgA}$ complex is less firm and sensitive to inhibition by $\alpha_{2}$-AP. Also the interactions of the $\gamma$-domain of $\mathrm{Sk}^{\mathrm{E}}$ with $\mathrm{Pg}$ could explain the faster generation of an active $\mathrm{Sk}^{\mathrm{E}}-\mathrm{Pg}$ complex (no lag phase in Pn generation was observed upon addition of $\mathrm{Sk}^{\mathrm{E}}$ to human $\mathrm{Pg}$, authors' unpublished observation) as compared to the $\mathrm{Sk}^{\mathrm{U}}-\mathrm{Pg}$ complex.

\section{ACKNOWLEDGMENT}

We thank Margit S. Rasmussen for excellent technical assistance.

\section{REFERENCES}

1. Boyle, M. D., and Lottenberg, R. (1997) Thromb. Haemostasis 77, $1-10$.

2. McCoy, H. E., Broder, C. C., and Lottenberg, R. J. (1991) Infect. Dis. 164, 515-521.

3. Reddy, K. N. N., and Markus, G. (1972) J. Biol. Chem. 247, 1683-1691.

4. Collen, D., Schlott, B., Engelborghs, Y., Van Hoef, B., Hartmann, M., Lijnen, H. R., and Behnke, D. (1993) J. Biol. Chem. 268, 8284-8289.

5. Grella, D. K., and Castellino, F. J. (1997) Blood 89, 15851589.

6. Parry, M. A. A., Fernandez-Catalan, C., Bergner, A., Huber, R., Hopfner, K.-P., Schlott, B., Gührs, K.-H., and Bode, W. (1998) Nat. Struct. Biol. 5, 917-923.

7. Wang, X., Lin, X., Loy, J. A., Tang, J., and Zhang, C. (1998) Science 281, 1662-1665.

8. Esmon, C. T., and Mather, T. (1998) Nat. Struct. Biol. 5, 933937.

9. Wang, S., Reed, G. L., and Hedstrom, L. (1999) Biochemistry $38,5332-5240$.

10. Young, K.-C., Shi, G.-Y., Chang, Y.-F., Chang, B.-I., Chang, L.-C., Lai, M.-D., Chuang, W.-J., and Wu, H.-L. (1998) J. Biol. Chem. 270, 29601-29606.
11. Nihalani, D., Rajesh, K., Rajagopal, K., and Sahni, G. (1998) Protein Science 7, 637-648.

12. Nihalani, D., Raghava, G. P. S., and Sahni, G. (1997) Protein Sci. 6, 1284-1292.

13. Johnsen, L. B., Poulsen, K., Kilian, M., and Petersen, T. E. (1999) Infect. Immun. 67, 1072-1078.

14. Johnsen, L. B., Ravn, P., Berglund, L., Petersen, T. E., Rasmussen, L. K., Heegaard, C. W., Rasmussen, J. T., Benfeldt, C., and Fedosov, S. N. (1998) Biochemistry 37, $12631-12639$.

15. Christensen, J. H., Hansen, P. K., Lillelund, O., and Thøgersen, H. C. (1991) FEBS Lett. 281, 181-184.

16. Studier, W., Rosenberg, A. H., Dunn, F. J., and Dubendorf, J. W. (1990) Methods Enzymol. 185, 60-89.

17. Chase, T., Jr., and Shaw, E. (1969) Biochemistry 8, $2212-$ 2224.

18. Andreasen, P. A., Nielsen, L. S., Kristensen, P., GrøndahlHansen, J., Skriver, L., and Danø, K. (1986) J. Biol. Chem. $261,7644-7651$.

19. Wohl, R. C., Summaria, L., and Robbins, K. C. (1980) J. Biol. Chem. 255, 2005-2013.

20. Wohl, R. C., Sinio, L., Summaria, L., and Robbins, K. C. (1983) Biochim. Biophys. Acta 745, 20-31.

21. Mendes, P. (1997) TIBS 22, 361-363.

22. Parrado, J., Conejero-Lara, F., Smith, R. A. G., Marshall, J. M., Ponting, C. P., and Dobson, C. M. (1996) Protein Sci. 5, 693-704.

23. McClintock, D. K., and Bell, P. H. (1971) Biochem. Biophys. Res. Commun. 43, 694-702.

24. Chaudhary, A., Vasundha, S., Rajagopal, K., Komath, S. S., Garg, N., Yadav, M., Mande, S. C., and Sahni, G. (1999) Protein Sci. 8, 2791-2805.

25. Rodriguez, P., Collen, D., and Lijnen, H. R. (1995) Fibrinolysis 9, 298-303.

26. Chibber, B. A. K., Morris, J. P., and Castellino, F. J. (1985) Biochemistry 24, 3429-3434.

27. Reed, G. L., Lin, L.-F., Parhami-Seren, B., and Kussie, P. (1995) Biochemistry 34, 10266-10271.

28. Collen, D., van Hoef, B., Schlott, B., Hartmann, M., Gûhrs, K.-H., and Lijnen, H. R.(1993) Eur. J. Biochem. 216, 307314.

29. Schlott, B., Gührs, K.-H., Hartmann, M., Röcker, A., and Collen, D. (1998) J. Biol. Chem. 273, 22346-22350.

30. Leigh, J. A. (1994) FEMS Microbiol. Lett. 118, 153-158.

31. Wulf, R. J., and Mertz, E. T. (1969) Can. J. Biochem. 47, 927-931.

32. Lijnen, H. R., and Collen, D. (1996) Fibrinolysis 10, 119126.

33. Cederholm-Williams, S. A., De Cock, F., Lijnen, H. R., and Collen, D. (1979) Eur J. Biochem. 100, 125-132.

34. Bode, W., and Huber, R. (1976) FEBS Lett. 68, 231-236. BI9922502 